International Scientific Organization http://iscientific.org/

Chemistry International

www.bosaljournals.com/chemint/

\title{
Modeling of Azadirachta indica leaves powder efficiency for the remediation of soil contaminated with crude oil
}

\author{
Chukwuemeka Peter Ukpaka* and Okon Nyong Eno
}

Department of Chemical/Petrochemical Engineering, Rivers State University Port Harcourt, PMB 5080, Rivers State, Nigeria

*Corresponding author's E. mail: chukwuemeka24@yahoo.com

\section{A R T I C L E I N F O}

\section{Article type:}

Research article

Article history:

Received October 2019

Accepted August 2020

January 2021 Issue

Keywords:

Regression analysis

Modeling

Azadirachta indica leaves

Crude oil

Remediation

Contaminated soil

\section{A B S T R A C T}

A regression analysis model was developed to examine the reliability and the acceptability of the sun-dried and room-dried Azadirachta indica leaves for the remediation crude oil contaminated soil in Niger Deltal, Nigeria. An experimental approach was used to monitor the concentration of the total petroleum hydrocarbon (TPH) degradation that was enhanced in the presence of the microbes in the reactor. A regression analysis was performed to evaluate the reaction behavior microbes in reactor for the remediation of the TPH in the presence of sun-dried and room-dried $A$. indica leaves in sandy and loamy soils contaminated with $100 \mathrm{ml}$ of crude oil. The physicochemical properties of control loamy soil was as; $\mathrm{pH}(6.75)$, electric conductivity $(10.36 \mu \mathrm{S} / \mathrm{cm})$, total oxygen $(2.99 \%)$, total Nitrogen $(0.091 \%)$, potassium $(36.82942 \%)$, phosphorus $(15.36 \%)$ and total bacteria $\left(2.15 \times 10^{2} \mathrm{cfu} / \mathrm{g}\right)$. Whereas, these values were as $\mathrm{pH}$ (6.82), electric conductivity $(21.48 \mu \mathrm{S} / \mathrm{cm})$, total oxygen content $(1.18 \%)$, total nitrogen $(0.036 \%)$, potassium $(24.03681 \%)$, phosphorus $(5.18 \%)$ and total bacteria count $\left(1.86 \times 10^{2} \mathrm{cfu} / \mathrm{g}\right)$ for sandy soil. The inoculant was prepared by blending sun-dried and room-dried $A$. indica leaves. The blended $A$. indica leaves in 50 to $100 \mathrm{~g}$ range were applied on the polluted soils for 35 days and significant reduction in contaminating agents was observed. The highest remediation was observed in soils treated with $100 \mathrm{~g}$ room dried A. indica leaves. A 96\% remediation recorded in sandy soil treated with $100 \mathrm{~g}$ room dried $A$. indica leaves as TPH depleted from $35818.69 \mathrm{mg} / \mathrm{kg}$ to $1349.109 \mathrm{mg} / \mathrm{kg}$ and $92 \%$ reduction was observed in loamy soil treated with $100 \mathrm{~g}$ dried $A$. indica leaves and TPH depleted from $48508.92 \mathrm{mg} / \mathrm{kg}$ to $3977.739 \mathrm{mg} / \mathrm{kg}$. The regression model developed was successfully employed to predict TPH remediation behavior, which can be applied to monitor remediation of contaminated soil.

(C) 2021 International Scientific Organization: All rights reserved.

Capsule Summary: A regression analysis model was developed to examine the remediation of soil contaminated with crude oil and developed model was successful in monitoring the TPH remediation of contaminated soil and could be used for monitoring the same for different radiating agents.

Cite This Article As: C. P. Ukpaka and O. N. Eno. Modeling of Azadirachta indica leaves powder efficiency for the remediation of soil contaminated with crude oil. Chemistry International 7(1) (2021) 62-70.

https://doi.org/10.5281/zenodo.4032367 


\section{INTRODUCTION}

Over the years, the association of plants and endophytic bacteria has gained much attention and salience. These alliances are very vital in maintaining mutual interactions among plants and bacteria, and contribute to the ecological balance between them (Hardoim, 2008; Khan, 2013; Santoyo, 2016). Endophytes are organisms (bacteria or fungi) that lives inside plant tissues, innocuous to their hosts, and results from much studies have indicated their positive effects on plant growth and development (Gaiero, 2013; Khan, 2013; Weyens, 2009). Consequently, they add support to the plant's adaptive mechanism to biotic and abiotic stresses, promote the availability of nitrogen, phosphorus and iron, activate the production of plant hormones and protect the plants against pathogens (Abbamondi, 2016; Compant, 2005; Glick, 2007; Naveed, 2014; Qin, 2015; Santoyo, 2016). In addition, endophytes effectively degrade and detoxify contaminants thereby increasing the plant's tolerance to the contaminants. Also, they reduce plant stress by producing 1aminocyclopropane-1-carboxylic acid (ACC) deaminase (Barac, 2004; Gaiero, 2013; Huang, 2005; Ryan, 2008). Endophytic bacteria consequently, were seen to be of remarkable importance in effective phytoremediation programs (Barac, 2004; Weyens, 2009).

Phytoremediation is an eco-friendly method of decontaminating contaminated soils and underground waters, using plants and their endophytes. This technology is considered promising and economically feasible for the decontamination of organic contaminants from soils (Vangronsveld, 2009; Weyens, 2009a). The Niger-Delta region of Nigeria has been prone to significant soil contamination and accumulation of aliphatic and aromatic hydrocarbons in the environment due to non-regulated disposal of oil sludge, oil extraction, refining and leakage during storage and transportation. Intensive investigations on the neutralization of these organic pollutants have been done because they exert harmful effects on living organisms (Huang, 2005; Khan, 2013; Wang, 2008). Recent results propose that for a successful phytoremediation, the major element is combining plants with endurance for high levels of contaminants with plant-associated endophytes capable of breaking down pollutants (Germaine, 2009; Yousaf, 2011). Moreover, it is proven that plants growing in crude oilpolluted soil can selectively boost the widespread of suitable endophytes containing genes encoding for enzymes responsible for hydrocarbon degradation (Oliveira, 2014; Siciliano, 2001). Other Authors has shown that the numbers of endophytes with hydrocarbon degradation capabilities has increased as a result of the advent of hydrocarbon contamination (Barac, 2004; Oliveira, 2014; Taghavi, 2009). This implies that investigating the variety of the plant endophytic community is imperative for the selection of useful strains for phytoremediation of soils contaminated with organics hence improving plant adaptation and growth. Because of the wide range of symbiosis between the plant host and its endophytes, their potential has great imputation for biotechnological applications during phytoremediation (Khan, 2013; Li, 2012). The greater the plant's endurance for soil polluted heavily with crude oil, the more useful tool they are for phytoremediation purposes.

In the past years, a plethora of research was carried out on the mechanisms of endophyte associated phytoremediation of pollutants in soils and promising efficiency is reported. Discussing their basic mechanisms, we will present updated information as regards progress, obstacles and new directions in the field of endophyte assisted phytoremediation technology (Ukpaka and Wami, 2017; Ukpaka, 2017; Ukpaka, 2020; Ukpaka et al., 2020).

This research proved to be a huge contribution to crude oil bioremediation in the following ways: The method used in this experiment for crude oil bioremediation is costeffective since the remedant is a widespread locally grown tree. This should counter previous methods proven to be very expensive. From the experiment, it is now easy to obtain the time required for the microbes to feed on the crude oil. Also, results from the experiment makes it easy to predict the actual quantity of $A$. indica leaves required to remediate a known quantity of crude oil. It was observed that $A$. indica leaves helps to replenish the natural NPK content of the crude oil polluted soil without adding fertilizers. It was also observed that $A$. indica leaves helps to stabilize the conductivity, $\mathrm{pH}$, microbial activity and salinity of the crude oil contaminated soil.

Table 1: Schematic representation of the experimental set-up

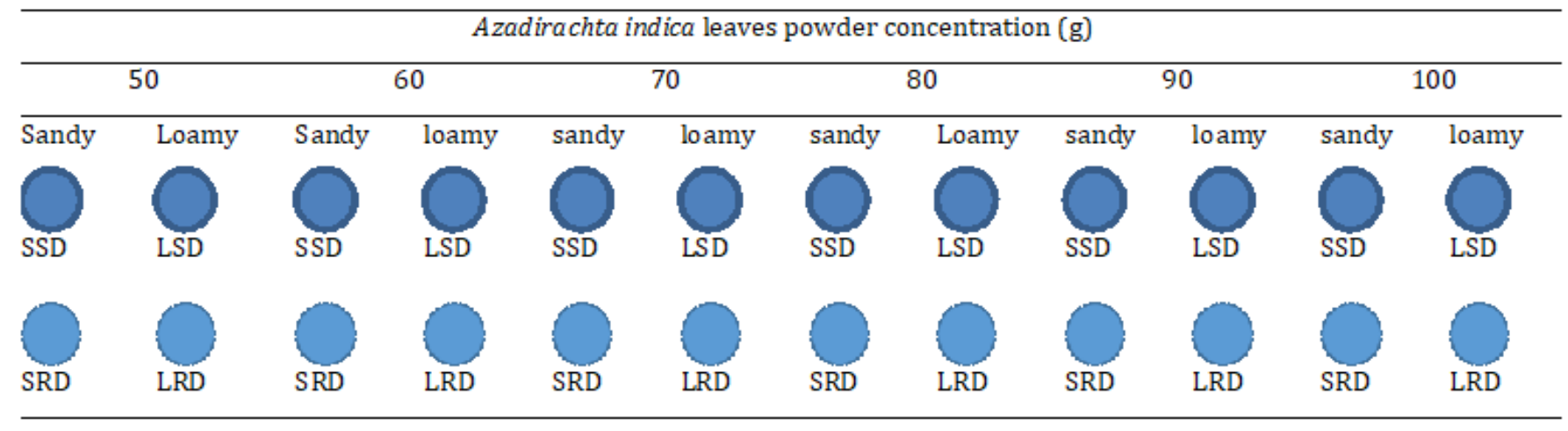


Table 2: TPH as a function of exposure time in soil treated with $50 \mathrm{~g}$ of $A$. indica leaves powder

\begin{tabular}{lllll}
\hline Time (days) & SSD $(\mathrm{ppm})$ & LSD $(\mathrm{ppm})$ & SRD $(\mathrm{ppm})$ & LRD $(\mathrm{ppm})$ \\
\hline 0 & 35818.69 & 48508.92 & 35818.69 & 48508.92 \\
7 & 34778.7 & 46177.42 & 33374.06 & 45709.09 \\
14 & 32381.02 & 43177.33 & 28375.86 & 40909.14 \\
21 & 32181.96 & 40771.2 & 26363.67 & 40006.84 \\
28 & 22880.75 & 32174.59 & 17669.36 & 29023.86 \\
35 & 11654.06 & 19339.89 & 7263.492 & 14807.66 \\
\hline
\end{tabular}

Table 3: TPH as a function of exposure time in soil treated with $60 \mathrm{~g}$ of $A$. indica leaves powder

\begin{tabular}{lllll}
\hline Time (days) & SSD $(\mathrm{ppm})$ & LSD $(\mathrm{ppm})$ & SRD $(\mathrm{ppm})$ & LRD $(\mathrm{ppm})$ \\
\hline 0 & 35818.69 & 48508.92 & 35818.69 & 48508.92 \\
7 & 32621.55 & 44507.49 & 32420.32 & 45045.42 \\
14 & 29992.84 & 40451.23 & 27245.78 & 38915.67 \\
21 & 26043.69 & 36210.31 & 23349.56 & 33751.86 \\
28 & 17167.24 & 26417.93 & 14568.15 & 31049.03 \\
34 & 15726.07 & 24199.65 & 13057.37 & 23276.2 \\
\hline
\end{tabular}

Table 4: TPH as a function of exposure time in soil treated with $70 \mathrm{~g}$ of $A$. indica leaves powder

\begin{tabular}{lllll}
\hline Time (days) & SSD $(\mathrm{ppm})$ & LSD $(\mathrm{ppm})$ & SRD $(\mathrm{ppm})$ & LRD $(\mathrm{ppm})$ \\
\hline 0 & 35818.69 & 48508.92 & 35818.69 & 48508.92 \\
7 & 32497.46 & 44769.44 & 32153.41 & 43949.71 \\
14 & 28423.68 & 39268.63 & 25530.19 & 35416.52 \\
21 & 24597.45 & 33945.52 & 20000.24 & 30243.79 \\
28 & 18097.89 & 28171.61 & 15193.53 & 24544.55 \\
35 & 10499 & 20408.04 & 7862.638 & 15331.41 \\
\hline
\end{tabular}

\section{MATERIAL AND METHODS}

\section{Material and equipment}

The soil samples and the $A$. indica leaves were obtained from a farm within Rivers State University vicinity. Materials that was used includes: sandy and loamy soil, crude oil (Bonny light), A. indica leaves, Melter weighing balance, beakers, $\mathrm{pH}$ meter for measuring decomposed sample, measuring cylinders, retort stands. Every $1 \mathrm{~kg}$ of soil was polluted with $100 \mathrm{ml}$ of crude oil. Thereafter, the remedants which were obtained by sun-drying and room-drying the Azadirachta Indica leaves were added into the reactors in varying quantities from $50 \mathrm{~g}$ to $100 \mathrm{~g}$ to ascertain its effects on the contaminated soil for 35 days. Characteristics of the soil will be taken before and after application of the pollution reagent (Bonny light).

\section{Sample preparation and experimental setup}

Twenty-six (26) reactors were used in the experiment of which 2 were control experiment containing crude oil contaminated soils without bioremediant. The other 24 reactors contained crude oil contaminated soils thoroughly mixed with varying quantities of either sun-dried or roomdried blended $A$. indica leaves. The crude oil sample obtained from was investigated for its Poly Aromatic Hydrocarbon and Total Petroleum Hydrocarbon content. The sandy and loamy soils were weighed $1 \mathrm{~kg}$ into thirteen places for each type of soil. Some of the A. indica leaves was sun-dried for 7 days and the others were room-dried for 14 days. Both the sun-dried and room-dried leaves were thoroughly blended. The weighed soil samples were contained in 26 reactors, $1 \mathrm{~kg}$ of soil to 1 reactor. Each $1 \mathrm{~kg}$ of soil sample was then contaminated with $100 \mathrm{ml}$ of crude by thorough mixing it 
Table 5: TPH as a function of exposure time in soil treated with $80 \mathrm{~g}$ of $A$. indica leaves powder

\begin{tabular}{lllll}
\hline Time (days) & SSD $(\mathrm{ppm})$ & LSD $(\mathrm{ppm})$ & SRD $(\mathrm{ppm})$ & LRD (ppm) \\
\hline 0 & 35818.69 & 48508.92 & 35818.69 & 48508.92 \\
7 & 31919.62 & 42636.48 & 31883.73 & 43967.03 \\
14 & 25683.22 & 34273.21 & 23390.61 & 33241.72 \\
21 & 25357.28 & 34035.58 & 21921.3 & 28240.6 \\
28 & 13013.31 & 18396.68 & 8296.345 & 17638.94 \\
35 & 5632.847 & 4538.681 & 4538.681 & 12252.9 \\
\hline
\end{tabular}

Table 6: TPH as a function of exposure time in in soil treated with $90 \mathrm{~g}$ of $A$. indica leaves powder

\begin{tabular}{lllll}
\hline Time (days) & SSD $(\mathrm{ppm})$ & LSD $(\mathrm{ppm})$ & SRD $(\mathrm{ppm})$ & LRD $(\mathrm{ppm})$ \\
\hline 0 & 35818.69 & 48508.92 & 35818.69 & 48508.92 \\
7 & 31717.64 & 42248.66 & 30441.2 & 40792.57 \\
14 & 23616.36 & 32797.83 & 19934.21 & 28460.65 \\
21 & 21268.04 & 28837.05 & 17744.23 & 21510.92 \\
28 & 11085.56 & 19888.24 & 8432.991 & 13894.15 \\
35 & 6513.655 & 8868.248 & 2198.7 & 6513.655 \\
\hline
\end{tabular}

Table 7: TPH as a function of exposure time in soil treated with $100 \mathrm{~g}$ of $A$. indica leaves powder

\begin{tabular}{lllll}
\hline Time (days) & SSD $(\mathrm{ppm})$ & LSD $(\mathrm{ppm})$ & SRD $(\mathrm{ppm})$ & LRD $(\mathrm{ppm})$ \\
\hline 0 & 35818.69 & 48508.92 & 35818.69 & 48508.92 \\
7 & 29860.58 & 41159.9 & 27969.31 & 38315.02 \\
14 & 19646.73 & 29005.54 & 15816.61 & 25273.57 \\
21 & 12323.34 & 21844.79 & 9236.23 & 18698.77 \\
28 & 6365.602 & 13771.45 & 3785.575 & 10236.94 \\
35 & 1604.248 & 6079.484 & 1349.109 & 3977.739 \\
\hline
\end{tabular}

with the soil. The blended sun-dried leaves were weighed ranging from $50 \mathrm{~g}$ to $100 \mathrm{~g}$ with one replicate for each measure. The room-dried leafs were weighed ranging from $50 \mathrm{~g}$ to $100 \mathrm{~g}$ with one replicate for each measure also. This summed up to 24 weighed blended leaf samples. The weighed leaf samples were systematically applied on 24 of the contaminated soil samples. Schematic representation of the experimental set up is shown in Table 1.

SSD represents the reactor containing sandy soil contaminated with crude oil and inoculated with blended sun-dried $A$. indica leaves. SRD is the same with SSD except that blended room-dried $A$. indica leaves were used instead of the sun-dried. To each type of soil contaminated with crude oil, quantities of either sun-dried or room-dried blended $A$. indica leaves ranging from $50 \mathrm{~g}$ to $100 \mathrm{~g}$ were added as illustrated in table 1. Each combination was thoroughly mixed to ensure uniformity of the components.

Before inoculation, the contaminated soils were analyzed for initial conditions like Total Hydrocarbon
Content, initial microbial activity, conductivity, $\mathrm{pH}$ etc. Subsequently, the 24 experimental samples were analyzed every week for a period of 5 weeks. Within this period, $10 \mathrm{ml}$ of water was added to each of the 24 inoculated soil samples to aid easy movement of microbes.

\section{Gas chromatographic analysis}

The soil sample was poured into a 1 liter separation funnel. A $50 \mathrm{~mL}$ of methylene chloride was added to the sample bottle seal and shook for 30 seconds to rinse the inner surface. The solvent was transferred to the separation funnel and then sample was extracted by shaking the funnel for 2 minutes with periodic venting to release excess pressure.

The organic layer was allowed to separate from the water phase for a minimum of 10 minutes and then the methylene chloride was extracted in a $250 \mathrm{~mL}$ flask. A second $60 \mathrm{~mL}$ volume of methylene chloride was added to the sample bottle. The separation funnel and the column were rinsed 
with $20 \mathrm{~mL}$ of the solvent into the extract. The extraction procedure was repeated a second time and combined with the other extract in an Erlenmeyer flask. The third extraction was performed in the same way. The combined extracts were poured through a drying column containing packed cotton wool, anhydrous sodium sulphate and silica. The extract was collected in the vial and concentrated by boiling it down with nitrogen gas to $1.0 \mathrm{~mL}$. The remaining extract was mixed with $1.0 \mathrm{~mL}$ of the solvent and $1.0 \mu \mathrm{L}$ was injected into the flame ionization detector gas chromatograph for the TPH analysis.

\section{RESULTS AND DISCUSSION}

The results obtained from this research work are presented in Tables and Figures. After 35 days of analyzing the soil samples at 7 days intervals, results were obtained. The results were then computed as presented in Table $2,3,4,5$, 6 and 7. The results presented in Table 2, 3, 4, 5, 6 and 7 were able to describe the effect of various quantity of $A$. indica leaves on Total Petroleum Hydrocarbon (TPH) degradation. Decrease in TPH was observed with increase in period of exposure for the various dosages.

\begin{tabular}{|c|c|c|c|}
\hline SSD: & $y=0.0165 x^{5}-1.4148 x^{4}+40.903 x^{3}+472.57 x^{2}+1600.8 x+35819$ & $R^{2}=1$ & (1) \\
\hline LSD: & $y=0.0083 x^{5}-0.7222 x^{4}+20.751 x^{3}-237.69 x^{2}+541.74 x+48509$ & $R^{2}=1$ & $(2)$ \\
\hline SRD: & $y=0.0148 x^{5}-1.2998 x^{4}+39.156 x^{3}-478.63 x^{2}+1492.8 x+35819$ & $R^{2}=1$ & (3) \\
\hline LRD: & $y=0.0202 x^{5}-1.7576 x^{4}+51.963 x^{3}-612.61 x^{2}+1896.5 x+48509$ & $R^{2}=1$ & (4) \\
\hline SSD: & $y=0.0098 x^{5}-0.718 x^{4}+17.194 x^{3}-159.6 x^{2}+40.574 x+35819$ & $R^{2}=1$ & (5) \\
\hline LSD: & $y=0.0129 x^{5}-0.9947 x^{4}+25.897 x^{3}-269.65 x^{2}+357.13 x+48509$ & $R^{2}=1$ & (6) \\
\hline SRD: & $y=0.0149 x^{5}-1.2018 x^{4}+33.728 x^{3}-390.77 x^{2}+973.7 x+35819$ & $R^{2}=1$ & (7) \\
\hline LRD: & $y=-0.049 x^{5}+0.3044 x^{4}-5.0435 x^{3}-0.5995 x^{2}-336.15 x+48509$ & $R^{2}=1$ & $(8)$ \\
\hline SSD: & $y=0.0042 x^{5}-0.3601 x^{4}+10.5 x^{3}-126.12 x^{2}+7.4017 x+35819$ & $R^{2}=1$ & (9) \\
\hline LSD: & $y=0.008 x^{5}-0.1021 x^{4}+4.2227 x^{3}-75.866 x^{2}-1.7703 x+48509$ & $R^{2}=1$ & $(10)$ \\
\hline SRD: & $y=0.0008 x^{5}-0.1303 x^{4}+6.5038 x^{3}-126 x^{2}+82.595 x+35819$ & $R^{2}=1$ & $(11)$ \\
\hline LRD: & $y=0.006 x^{5}-0.6154 x^{4}+22.05 x^{3}-323.42 x^{2}+728.88 x+48509$ & $R^{2}=1$ & $(12)$ \\
\hline SSD: & $y=0.0303 x^{5}-2.5744 x^{4}+75.031 x^{3}-872.3 x^{2}+2682.9 x+35819$ & $R^{2}=1$ & (13) \\
\hline LSD: & $y=0.0371 x^{5}-3.1905 x^{4}+93.695 x^{3}-1089.6 x^{2}+3202.6 x+48509$ & $R^{2}=1$ & (14) \\
\hline SRD: & $y=0.0357 x^{5}-3.0315 x^{4}+89.242 x^{3}-1064.4 x^{2}+3469.7 x+35819$ & $R^{2}=1$ & $(15)$ \\
\hline LRD: & $y=0.0225 x^{5}-1.978 x^{4}+61.302 x^{3}-787.74 x^{2}+2486 x+48509$ & $R^{2}=1$ & $(16)$ \\
\hline SSD: & $y=0.025 x^{5}-2.1534 x^{4}+64.585 x^{3}-787 x^{2}+2437.1 x+35819$ & $R^{2}=1$ & $(17)$ \\
\hline LSD: & $y=0.0161 x^{5}-1.4623 x^{4}+45.864 x^{3}-577.16 x^{2}+1361.3 x+48509$ & $R^{2}=1$ & $(18)$ \\
\hline SRD: & $y=0.027 x^{5}-2.3936 x^{4}+73.948 x^{3}-923.35 x^{2}+2827.8 x+35819$ & $R^{2}=1$ & $(19)$ \\
\hline LRD: & $y=0.0114 x^{5}-1.0767 x^{4}+36.112 x^{3}-494.79 x^{2}+933.67 x+48509$ & $R^{2}=1$ & $(20)$ \\
\hline SSD: & $y=0.005 x^{5}-0.4985 x^{4}+18.318 x^{3}-282.71 x^{2}+389.27 x+35819$ & $R^{2}=1$ & $(21)$ \\
\hline LSD: & $y=0.0114 x^{5}-1.0675 x^{4}+35.686 x^{3}-490.7 x^{2}+975.33 x+48509$ & $R^{2}=1$ & $(22)$ \\
\hline SRD: & $y=0.0102 x^{5}-0.965 x^{4}+32.79 x^{3}-454.17 x^{2}+757.54 x+35819$ & $R^{2}=1$ & $(23)$ \\
\hline LRD: & $y=0.0149 x^{5}-1.3517 x^{4}+43.008 x^{3}-545.41 x^{2}+681.98 x+48509$ & $R^{2}=1$ & $(24)$ \\
\hline \multicolumn{3}{|c|}{$y=0.005(5)^{5}-0.4985(5)^{4}+18.318(5)^{3}-282.71(5)^{2}+389.27(5)+35819=32832.04$} & $(25)$ \\
\hline \multicolumn{3}{|c|}{$y=0.005(10)^{5}-0.4985(10)^{4}+18.318(10)^{3}-282.71(10)^{2}+389.27(10)+35819=25273.7$} & (26) \\
\hline \multicolumn{3}{|c|}{$y=0.005(15)^{5}-0.4985(15)^{4}+18.318(15)^{3}-282.71(15)^{2}+389.27(15)+35819=18431.860$} & (27) \\
\hline \multicolumn{3}{|c|}{$y=0.005(20)^{5}-0.4985(20)^{4}+18.318(20)^{3}-282.71(20)^{2}+389.27(20)+35819=13304.4$} & $(28)$ \\
\hline \multicolumn{3}{|c|}{$y=0.005(25)^{5}-0.4985(25)^{4}+18.318(25)^{3}-282.71(25)^{2}+389.27(25)+35819=9177.3$} & (29) \\
\hline \multicolumn{3}{|c|}{$y=0.0114(5)^{5}-1.0675(5)^{4}+35.686(5)^{3}-490.7(5)^{2}+975.33(5)+48509=44946.58$} & $(30)$ \\
\hline \multicolumn{3}{|c|}{$y=0.0114(10)^{5}-1.0675(10)^{4}+35.686(10)^{3}-490.7(10)^{2}+975.33(10)+48509=35337.3$} & $(31)$ \\
\hline \multicolumn{3}{|c|}{$y=0.0114(15)^{5}-1.0675(15)^{4}+35.686(15)^{3}-490.7(15)^{2}+975.33(15)+48509=27766.14$} & $(32)$ \\
\hline \multicolumn{3}{|c|}{$y=0.0114(20)^{5}-1.0675(20)^{4}+35.686(20)^{3}-490.7(20)^{2}+975.33(20)+48509=22855.6$} & (33) \\
\hline \multicolumn{3}{|c|}{$y=0.0114(25)^{5}-1.0675(25)^{4}+35.686(25)^{3}-490.7(25)^{2}+975.33(25)+48509=18040.68$} & (34) \\
\hline \multicolumn{3}{|c|}{$y=0.0102(5)^{5}-0.965(5)^{4}+32.79(5)^{3}-454.17(5)^{2}+757.54(5)+35819=42861.4$} & $(35)$ \\
\hline \multicolumn{3}{|c|}{$y=0.0102(10)^{5}-0.965(10)^{4}+32.79(10)^{3}-454.17(10)^{2}+757.54(10)+35819=22137.4$} & $(36)$ \\
\hline \multicolumn{3}{|c|}{$y=0.0102(15)^{5}-0.965(15)^{4}+32.79(15)^{3}-454.17(15)^{2}+757.54(15)+35819=14552.6$} & $(37)$ \\
\hline \multicolumn{3}{|c|}{$y=0.0102(20)^{5}-0.965(20)^{4}+32.79(20)^{3}-454.17(20)^{2}+757.54(20)+35819=9861.8$} & (38) \\
\hline \multicolumn{3}{|c|}{$y=0.0102(25)^{5}-0.965(25)^{4}+32.79(25)^{3}-454.17(25)^{2}+757.54(15)+35819=5901.25$} & (39) \\
\hline \multicolumn{3}{|c|}{$y=0.0149(5)^{5}-1.3517(5)^{4}+43.008(5)^{3}-545.41(5)^{2}+681.98(5)+48509=42861.4$} & $(40)$ \\
\hline \multicolumn{3}{|c|}{$y=0.0149(10)^{5}-1.3517(10)^{4}+43.008(10)^{3}-545.41(10)^{2}+681.98(10)+48509=31768.8$} & $(41)$ \\
\hline \multicolumn{3}{|c|}{$y=0.0149(15)^{5}-1.3517(15)^{4}+43.008(15)^{3}-545.41(15)^{2}+681.98(15)+48509=24058.33$} & $(42)$ \\
\hline \multicolumn{3}{|c|}{$y=0.0149(20)^{5}-1.3517(20)^{4}+43.008(20)^{3}-545.41(20)^{2}+681.98(20)+48509=19456.6$} & $(43)$ \\
\hline \multicolumn{3}{|c|}{$y=0.0149(25)^{5}-1.3517(25)^{4}+43.008(25)^{3}-545.41(25)^{2}+681.98(25)+48509=14177.25$} & $(44)$ \\
\hline
\end{tabular}




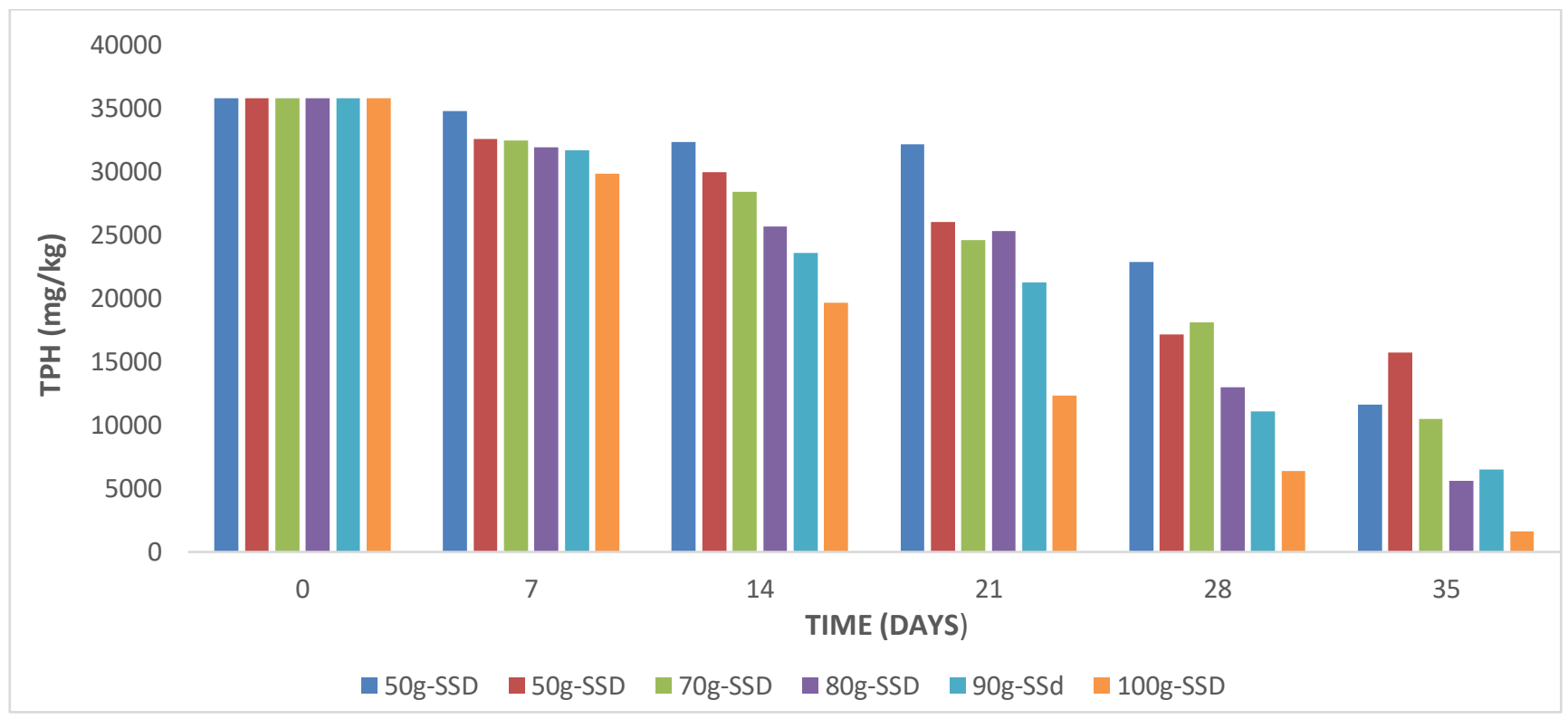

Fig. 1: TPH remediation in sandy soils using varying quantities of blended sun dried $A$. indica leaves

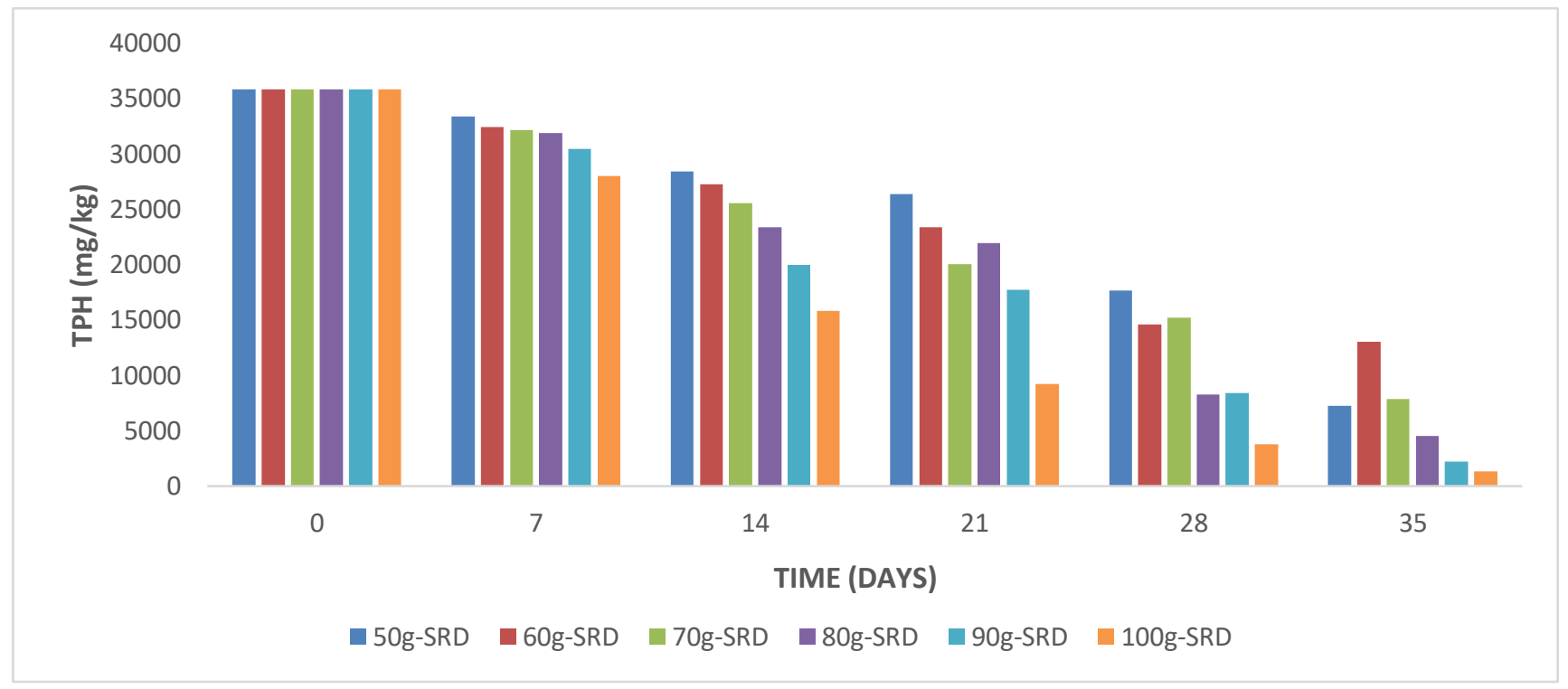

Fig. 2: TPH remediation in sandy soils using varying quantities of blended room-dried $A$. indica leaves

The soil and crude oil used in the experiment were subjected to physicochemical tests to ascertain their physical and chemical constituents. The results are shown in the Tables 2-7.

\section{Models for the different quantities of $\boldsymbol{A}$. indica leaves}

The least square method was used to compute the model that best fits each of the plots. In the model, y represents $\mathrm{TPH}$ and $\mathrm{x}$ represents Time. The regression analysis of $50 \mathrm{~g}$
A. indica leaves (TPH vs time) is shown in Eqs. 1-4, whereas Eqs. 5-8 showed the regression analysis of $60 \mathrm{~g} \mathrm{~A}$. indica leaves (TPH vs time) and regression analysis of $70 \mathrm{~g} A$. indica leaves (TPH vs time) are shown in Eqs. 9-12. Regression analysis of $80 \mathrm{~g} A$. indica leaves (TPH vs time) is shown in Eqs. 13-16, while regression analysis of $90 \mathrm{~g} A$. indica leaves (TPH vs time) is shown in Eqs. 17-20. 13-16 and for $100 \mathrm{~g} \mathrm{~A}$. indica leaves (TPH vs time), it is shown in Eqs. 21-24. 


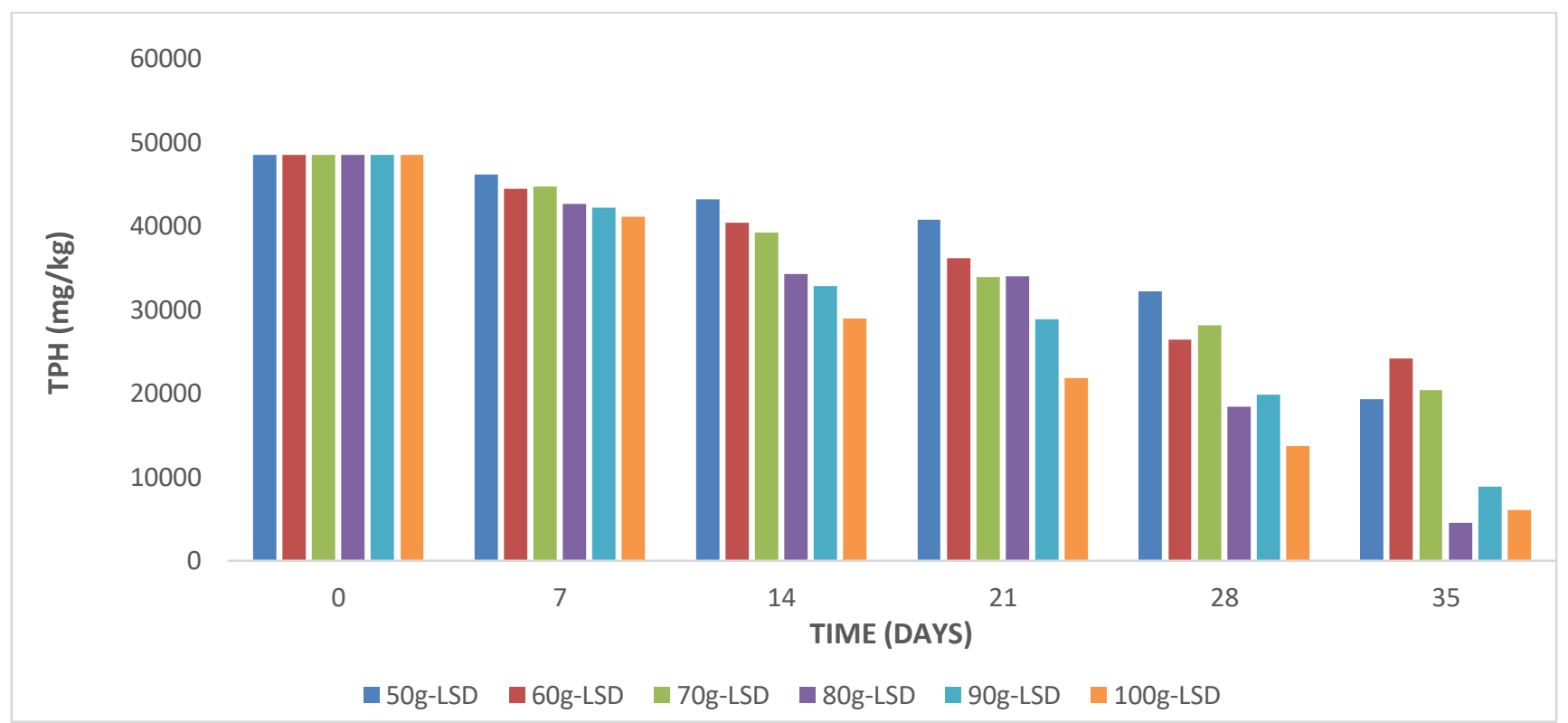

Fig. 3: TPH remediation in loamy soils using varying quantities of blended sun dried $A$. indica leaves

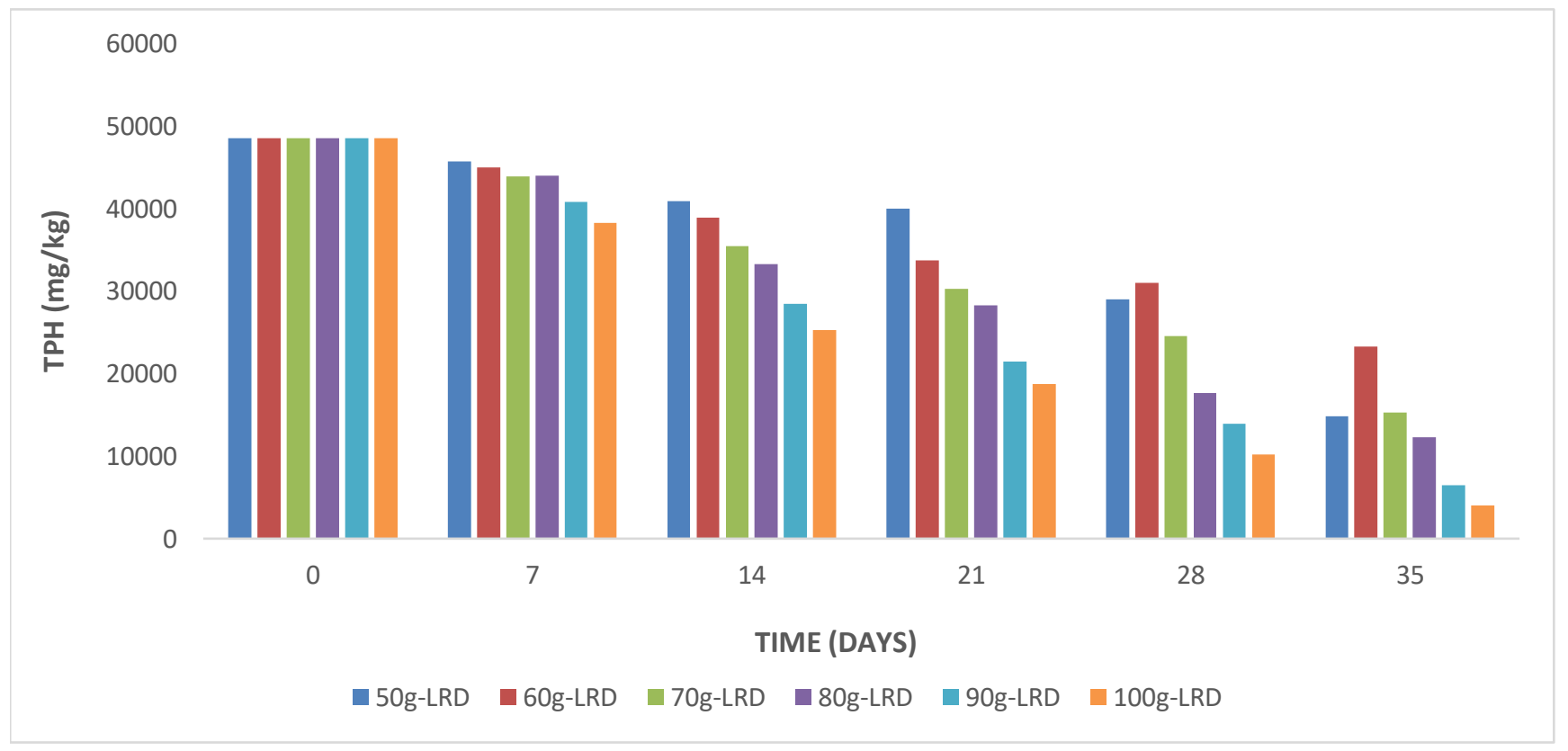

Fig. 4: TPH remediation in loamy soils using varying quantities of blended room-dried $A$. indica leaves

Having accuracies of $100 \%$, these models can be used to predict the amount of TPH remediated at any other time. For instance, the TPH remediated at the fifth, tenth, fifteenth, twentieth and twenty-fifth day can be estimated by simply imputing any of the afore-stated days as a value of $\mathrm{x}$ in the models expressing either SSD, LSD, SRD or LRD. For $100 \mathrm{~g} \mathrm{SSD}$ at the $5^{\text {th }}, 10^{\text {th }}, 15^{\text {th }}, 20^{\text {th }}$, and $25^{\text {th }}$ day the regressions are shown in Eqs. 25-29, whereas, the regressions for $100 \mathrm{~g}$ LSD at the $5^{\text {th }}, 10^{\text {th }}, 15^{\text {th }}, 20^{\text {th }}$, and $25^{\text {th }}$ day are shown in Eqs. 30-34 and the SRD regressions for

www.bosaljournals/chemint/
$100 \mathrm{~g}$ at the $5^{\text {th }}, 10^{\text {th }}, 15^{\text {th }}, 20^{\text {th }}$, and $25^{\text {th }}$ day are shown in Eqs. 35-39 and for $100 \mathrm{~g} \mathrm{LRD}$ at the $5^{\text {th }}, 10^{\text {th }}, 15^{\text {th }}, 20^{\text {th }}$, and $25^{\text {th }}$ day, the regressions are shown in Eqs. 40-44.

The estimated values of TPH obtained from the regression models were seen to follow the trail of the experimental values of TPH. That is, the TPH estimated falls in line with the TPH obtained from experiment. For instance, TPH for SSD at the fifth day was estimated to be $32832.04 \mathrm{mg} / \mathrm{kg}$ which is a good precedence for the experimental TPH of SSD at the seventh day observed to be

\section{8}


$29860.58 \mathrm{mg} / \mathrm{kg}$. Also, TPH estimated for LRD at the twentieth day is $19456.6 \mathrm{mg} / \mathrm{kg}$, a good precedence for the experimental TPH of LRD at the twenty-first day observed to be $18698.77 \mathrm{mg} / \mathrm{kg}$.

\section{Sandy soils treated with sundried $A$. indica leaves (SSD)}

Crude oil contaminated sandy soils treated with sundried $A$. Indica leaves were observed to contain the same amount of total petroleum hydrocarbon content (TPH) at the preliminary stage of the experiment as described in Figure 1. As shown in Figure 2, for a period of day 7 to day 14, it can be observed that TPH reduced with respect to quantity of $A$. Indica leaves used. This could be as a result of lot of factors of which most prominent is the steady exponential growth of hydrocarbon degraders (microbes) in each sample with respect to the quantity of $A$. Indica leaves used. Subsequently from day 21 to day 35 , it can be observed that the reduction of TPH was erratic and did not completely follow the idea that the higher the quantity of the inoculant (Azadirachta indica), the greater the remediation. For instance, at day 35, it can be seen that $50 \mathrm{~g}$ of the inoculant caused more remediation than $60 \mathrm{~g}$ of inoculant.

\section{Sandy soil treated with room-dried $A$. indica leaves (SRD)}

This set of samples also followed the trend of SSD as it can be observed that at the beginning of the experiment, all the samples maintained the same range of TPH. From day 7 to day 14 , the TPH is observed to also deplete with respect to the amount of $A$. indica leaves used. This is illustrated in Figure 2. For a period of day 21 to day 35, it can be seen that TPH depletion with respect to amount of inoculant used exhibited some irregularities among each group of data. That is, where some samples with lesser quantities of inoculants gave better remediation results than samples with higher quantities of inoculants.

\section{Loamy soil treated with sundried $A$. indica leaves (LSD)}

Crude oil contaminated Loamy soils treated with sundried $A$. indica leaves were observed to contain the same amount of total petroleum hydrocarbon content (TPH) at the preliminary stage of the experiment as described in Figure 3. From Figure 3, it can be observed that TPH reduced with respect to quantity of $A$. indica leaves used for a period of day 7 to day 14, . This could be as a result of lot of factors of which most prominent is the steady exponential growth of hydrocarbon degraders (microbes) in each sample with respect to the quantity of $A$. indica leaves used. Subsequently from day 21 to day 35, it can be observed that the reduction of TPH was erratic and did not completely follow the idea that the higher the quantity of the inoculant (A. indica), the greater the remediation. For instance, at day 35 , it can be seen that $80 \mathrm{~g}$ of the inoculant caused more remediation than $100 \mathrm{~g}$ of inoculant.

\section{Loamy soils treated with room-dried $A$. indica leaves (LRD)}

This set of samples also followed the trend of SRD as it can be observed that at the beginning of the experiment, all the samples maintained the same range of TPH. From day 7 to day 14, the TPH is observed to also deplete with respect to the amount of $A$. indica leaves used. This is illustrated in Figure 4. For a period of day 21 to day 35, it can be seen that TPH depletion with respect to amount of inoculant used exhibited some irregularities among each group of the data. That is, where some samples with lesser quantities of inoculants gave better remediation results than samples with higher quantities of inoculants.

In the long run, it was observed that sandy soil treated with $100 \mathrm{~g}$ of blended room-dried $A$. indica leaves had the highest remediation as its TPH content dropped from $35818.69 \mathrm{mg} / \mathrm{kg}$ to $1349.109 \mathrm{mg} / \mathrm{kg}$ in 35 days. It was also observed that loamy soil treated with sundried $A$. indica leaves had the lowest remediation as its TPH dropped from $48508.92 \mathrm{mg} / \mathrm{kg}$ to $24199.65 \mathrm{mg} / \mathrm{kg}$ in 35 days. Based on findings, it can be concluded that $A$. indica leaves powder is efficient to remediate soil contaminated with crude oil, which is one major issue of the soil contamination and using remediation agents form natural resource is cost effective and ecofriendly (Deivakumari et al., 2020; Ferguson et al., 2020; Kang et al., 2020; Vasilyeva et al., 2020).

\section{CONCLUSIONS}

In tandem with the objectives of this research, the following conclusion was drawn; $A$. indica leaves is a good crude oil bioremedant. Blended Room dried $A$. indica leaves gives better crude oil remediation compared to the sundried. Crude oil remediation occurs faster in sandy soils than in loamy soils. Every $1 \mathrm{~kg}$ of soil polluted with $100 \mathrm{ml}$ of crude oil requires $100 \mathrm{~g}$ of blended room dried $A$. indica leaves to achieve significant remediation of its TPH in 35 days. Oxygenation by addition of water enhances the rate of bioremediation In the course of the experiment, some limitations were experienced and adequate innovative ideas were put together to counter these limitations. In Subsequent research regarding treating crude oil contaminated soils using $A$. Indica leaves. Based on observation, the recommendations are as; larger quantity of $A$. indica leaves should be used. Comparisons should be made between Wetblended $A$. indica leaves and room-dried $A$. indica leaves in crude oil remediation. The soil samples should be moisturized with water at intervals to enable the proliferation of micro-organisms in the soil. The soil samples should be stirred at intervals to enable the movement of micro-organisms within the soil and long term experiment should be carried out for a longer period to monitor the TPH properly.

\section{REFERENCES}


Abbamondi, G.R, Weyens, T.G., 2016. Plant growth-promoting effects of rhizospheric and endophytic bacteria associated with different tomato cultivars and new tomato hybrid. Chemical and Biological Technologies in Agriculture 3, 1-6.

Barac, T., Targhavi, S., 2004. Engineered endophytic bacteria improve phytoremediation of water-soluble, volatile, organic pollutants. Nature Biotechnology 22, 583-588.

Compant, S, Duffy, B., 2005. Use of plant growth-promoting bacteria for biocontrol of plant diseases: principles, mechanisms of action, and future prospects. Applied and Environmental Microbiology 71, 4951-4959.

Deivakumari, M., Sanjivkumar, M., Suganya, A.M., Prabakaran, J.R., Palavesam, A., Immanuel, G., 2020. Studies on reclamation of crude oil polluted soil by biosurfactant producing Pseudomonas aeruginosa (DKB1). Biocatalysis and Agricultural Biotechnology 29, 101773.

Ferguson, D.K., Li, C., Jiang, C., Chakraborty, A., Grasby, S.E., Hubert, C.R.J., 2020. Natural attenuation of spilled crude oil by cold-adapted soil bacterial communities at a decommissioned High Arctic oil well site. Science of The Total Environment 722, 137258.

Gaiero, J., McAll, C., Thompson K., 2013. Inside the root microbiome: bacterial root endophytes and plant growth promotion. American Journal of Botany 100, 1738-1750.

Germaine, K., Keogh, E., Ryan, D., 2009. Bacterial endophytemediated naphthalene phytoprotection and phytoremediation. Federation of European Microbiological Societies Microbiology Letters 296, 226234.

Glick, B, Todorovic, B., Czarny, J., 2007. Promotion of plant growth by bacterial ACC deaminase. Critical Review in Plant Sciences 26, 227-242.

Hardoim, P., Van, O., 2008. Properties of bacterial endophytes and their proposed role in plant growth. Trends in Microbiology 16, 463-471.

Huang, X., El-Alawi, Y., 2005. A multi-process phytoremediation system for decontamination of persistent total petroleum hydrocarbons (TPHs) from soils. Microchemical Journal 81, 139-147.

Kang, C.-U., Kim, D.-H., Khan, M.A., Kumar, R., Ji, S.-E., Choi, K.W., Paeng, K.-J., Park, S., Jeon, B.-H., 2020. Pyrolytic remediation of crude oil-contaminated soil. Science of The Total Environment 713, 136498.

Khan, S., Afzal, M., Iqbal, S., Khan, M., 2013. Plant-bacteria partnerships for the remediation of hydrocarbon contaminated soils. Chemosphere 4, 1317-1332.

Li, H., Wei, D., Shen, M., 2012. Endophytes and their role in phytoremediation. Fungal Divers 1, 11-18.

Naveed, M., Mitter, B., Yousaf, S., 2014. The endophyte Enterobacter sp. FD17: a maize growth enhancer selected based on rigorous testing of plant beneficial traits and colonization characteristics. Biology and Fertility of Soils 50, 249-262.

Oliveira, V., Gomez, N., Almeida, A., 2014. Hydrocarbon contamination and plant species determine the phylogenetic and functional diversity of endophytic degrading bacteria. Molecular Ecology 23, 1392-1404.

Qin, S., Miao, Q., Feng, W., 2015. Biodiversity and plant growth promoting traits of culturable endophytic actinobacteria associated with Jatropha curcas L. growing in Panxi dry-hot valley soil. Applied Soil Ecology 93, 47-55.

Ryan, R., Germaine, K., Franks, A., 2008. Bacterial endophytes: recent developments and applications, Federation of European Microbiological Societies Microbiology Letters 278, 1-9.

Santoyo, G., Moreno-Hagelsie, G., Carmen, M., 2016. Plant growth-promoting bacterial endophytes. Microbiol Research 183, 92-99.

Siciliano, S., Fortin, N., Mihoc, A., 2001. Selection of specific endophytic bacterial genotypes by plants in response to soil contamination. Applied and Environmental Microbiology 67, 2469-2475.

Taghavi S., Garavola C., Monchy S., 2009. Genome survey and characterization of endophytic bacteria exhibiting a beneficial effect on growth and development of poplar trees. Applied Environmental Microbiology 75, 748-757.

Ukpaka, C., Wami, E., 2017. Degradation biokinetics of used and fresh lube oils in contaminated soil environment. Chemistry International 3, 494-507.

Ukpaka, C.P., 2017. BTX Degradation: The concept of microbial integration. Chemistry International 3, 8-18.

Ukpaka, C.P., 2020. Development of mathematical model to predict the quantum energy of an electron in an orbit of hydrogen, lithium and sodium. Chemistry International 6, 179-186.

Ukpaka, C.P., Lezorghia, S.B., Nwosu, H., 2020. Crude oil degradation in loamy soil using Neem root extracts: An experimental study. Chemistry International 6, 160-167.

Vangronsveld, J., Herzeg, R., Weyens N., 2009. Phytoremediation of contaminated soils and groundwater: lessons from the field. Evironmental Science and Pollution Research 16, 765-794.

Vasilyeva, G., Kondrashina, V., Strijakova, E., Ortega-Calvo, J.J., 2020. Adsorptive bioremediation of soil highly contaminated with crude oil. Science of The Total Environment 706, 135739.

Wang, J, Zhang, Z., Su, Y., 2008. Phytoremediation of petroleum polluted soil. Petroleum Science 5, 167-171.

Weyens, N, Targhavi S., Barac, T., 2009. Bacteria associated with oak and ash on a TCE-contaminated site: characterization of isolates with potential to avoid evapotranspiration. Environmental Science and Pollution Research 16, 830-843.

Yousaf, S., Afzal, M., Reichenauer, T., 2011. Hydrocarbon degradation, plant colonization and gene expression of alkane degradation genes by endophytic Enterobacter ludwigii strains. Environmental Pollution 10, 2675-2683.

Visit us at: http://bosaljournals.com/chemint/ Submissions are accepted at: editorci@bosaljournals.com 